\title{
Husserl on Kant and the critical view of logic 1
}

\author{
Mirja Hartimo \\ Tampere University \\ Finland
}

The sciences are dogmatic, they are the sciences which require "criticism" —and, indeed, a criticism, which they themselves are essentially incapable of effecting; and, on the other hand, that science having the unique function of effecting the criticism of all others and, at the same time, of itself is none other than phenomenology (Ideas I, §62).

But for us, who are striving toward a radical logic, the attitude of Kant's transcendental philosophy toward formal logic is of particular interest (Formal and Transcendental Logic, 265/258)

Abstract: This paper seeks to clarify Husserl's critical remarks about Kant's view of logic by comparing their respective views of logic. In his Formal and Transcendental Logic (1929, §100) Husserl criticizes Kant for not asking transcendental questions about formal logic, but rather ascribing an "extraondinary apriority" to it. He thinks the reason for Kant's uncritical attitude to logic lies in Kant's view of logic as directed towards the subjective, instead of being concerned with a "world' of ideal Objects." The paper argues that Husserl's complaint stems from the fact that, for Kant, general logic is about laws of reasoning. Husserl, on the other hand, thinks that formal logic should describe formal structures. Husserl claims that if Kant had had a more comprehensive concept of logic, he would have thought of raising critical questions about how logic is possible. Even though Kant is in one sense critical of the logic of his time, this is not the sense intended

\footnotetext{
${ }^{1}$ I want to thank Frode Kjosavik, Øystein Linnebo, Fredrik Westerlund, Sara Heinämaa, and Ofra Rechter for many valuable comments on earlier versions of this paper.
} 
by Husserl. Husserl holds that logic should be subjected to transcendental criticism. Such criticism cannot itself use forms of judgments or syllogisms of logic, nor even the "inferential" [schliessende] method more generally, but should be descriptive in nature. The paper ends with a characterization of the way in which Husserl's view of logic is critical and with a brief comparison with Charles Parsons's 'critical view of logic.' It will be argued that, in combination, these two approaches could help formulating a viable critical view of logic needed for contemporary discussions of logic's foundations and status.

\section{Introduction}

As a species of transcendental philosophy, Husserl's phenomenology shares Kant's critical attitude toward sciences. Like Kant, Husserl demands asking critical questions about the conditions of possibility about the sciences. Indeed, Husserl's primary complaint about Kant is that Kant was not critical enough:

his [Kant's] system can certainly be characterized, in the general sense defined, as one of 'transcendental philosophy,' although it is far from accomplishing a truly radical grounding of philosophy, the totality of all sciences. (Crisis, §27)

Husserl holds that Kant fails to extend his transcendental, how is $\mathrm{X}$ possible' questions to all sciences. Logic, in particular, is excluded from the critical questioning. The heart of Husserl's criticism of Kant in his mature Formal and Transcendental Logic (1929, hereafter FTL) ${ }^{2}$ is that Kant failed to ask transcendental questions about formal logic:

However greatly Kant surpassed his contemporaries, and however much his philosophy remains for us a source of profound stimulations, the half-way character of his advancement of a systematic transcendental philosophy is shown by the fact that, although to be sure he did not, like English empiricism, regard formal logic (taken as syllogistics, Kant's 'reine und allgemeine' logic) as mostly a worthless scholastic survival or, again like empiricism (with respect to the parts

\footnotetext{
${ }^{2}$ I will refer to FTL with page numbers so that the first number is to the German original and the second to the English translation. To refer to all editions in all languages at once, the references to Husserl's other works are to section numbers instead of page numbers.
} 
of logic it accepted), rob that discipline of its peculiar genuine sense by a psychologistic reinterpretation [Umdeutung] of its ideality, still he asked no transcendental questions about it, but rather ascribed to it an extraordinary apriority, which exalts it above such questions. (FTL, 265/258)

Without referring to any exact passages in Kant, Husserl identifies Kant's view of general and pure logic as the reason why Kant excludes it from any transcendental scrutiny. Husserl's explanation is that Kant failed to see this because he failed to appreciate the significance of ideal formations and, in particular, their place as the thematic sphere of logic. Consequently, Kant could not ask transcendental questions aboutit:

Pure logic has as its thematic sphere ideal formations. But they would have had to be clearly seen, and definitely apprehended [bestimmt gefa $\beta$ t sein], as such ideal objectivities, before transcendental questions about them and about pure logic could have been asked. (FTL, 265/258)

In Husserl's view, logic is primarily concerned with formal theories about abstract objects, hence it is on a par with empirical sciences. Indeed, by means of logic, he wanted to capture the common pure structures of the axiomatic theories (cf. Hartimo 2018). Accordingly, for Husserl, the origin of logic is in Plato, and in geometry, rather than in Aristotle's syllogistics and Posterior Analytics (FTL 1/ 1). Being inspired also by Leibniz, Bolzano, and Lotze, Husserl held that the ideality of the formations with which logic is concerned is "the characteristic of a separate, self-contained, 'world' of ideal objects" (FTL, 267/261). Husserl's contends that, had Kant realized this, he would not have restricted the domain accounted for by his transcendental question of "how natural science is possible" to empirical objects, but would have noticed the need to account for also the world of ideal objectivities (i.e., abstract objects, in contemporary parlance).

To put it briefly, in FTL Husserl holds that Kant failed to subject logic to transcendental criticism because he did not recognize the proper extent of the abstract, or what he calls "ideal," logical realm. Whereas for Kant, general logic is about laws of reasoning, Husserl's view of formal logic includes the formal objects it is about. While it is debatable whether Kant thinks there are formal (mathematical) objects at all (cf. 
Parsons 2012, 43-49), Husserl's view of logic encompasses abstract structural mathematics. Whereas Kant, in Husserl's eyes, uses general logic in several ways to determine the scope and limits of reason, Husserl holds that logic, too, has to be subjected to transcendental criticism. This is also the course of Husserl's argument in FTL. He first displays his view of formal logic. After this, he is in a position to examine its conditions of possibility, which is what he does in the second part of the book, on transcendental logic. In the end, Husserl's conception of transcendental logic, which is very different from Kant's conception thereof, manifests the kind of critique formal logic should be subjected to. To be sure, 'critique' here means having been subjected to transcendental how is X possible' questions.

In what follows, I will try to clarify Husserl's view. I will first explain his criticism of Kant's general logic by elaborating on the differences in their respective conceptions of logic. In the end, I will expand on the critical view of logic Husserl thinks we should adopt. This will also serve as a useful starting point for a discussion of what a critical view of logic should be in contemporary debates about logic's foundations and status. A comparison with Parsons's critical view of logic in the end of the paper helps to further understand Husserl's view of logic and to develop general guidelines for a pertinent contemporary critique of logic.

2. Husserl on Kant and the pure and general logic

In his charge that general logic is being directed towards the subjective in Kant, Husserl seems to be referring to Kant's view that general logic is about thinking, whereas Husserl holds that it should be about the objects of thought. In this sense, Husserl's conception of Kant's general logic seems correct: Kant writes that general logic is concerned with "absolutely necessary rules of thinking, without which no use of the understanding takes place" (A52/ B76). It is general, since "it abstracts from all contents of the cognition of the understanding and of the difference of its objects, and has to do with nothing but the mere form of thinking" (A54/B78). It is pure, because "it has no empirical principles, thus it draws nothing from psychology" (A54/B78). Kant's pure and general logic is a priori, pure, general, and independent of empirical psychology. Yet 
it is concerned with the subjective in Husserl's view, because it is about thinking, i.e., about subjective acts, rather than about objective structures. (For more details on Kant's view of logic, see Kjosavik's paper on the topic in the present issue).

Somewhat polemically, Husserl attributes the standpoint of the Aristotelian-Scholastic logic to it:

Shall this unutterably defective logic be the model we should strive to imitate? No one will look kindly on the thought of pushing science back to the standpoint of the Aristotelian-Scholastic logic, which seems what Kant's treatment amounts to, since he himself says that logic has had the character of a closed science since the time of Aristotle. (Prolegomena, §58)

This complaint about Kant's view of logic seems to be, even in Husserl's own eyes, exaggerated. According to Kant, general logic is a "concise and dry" science, "as the methodical expositions of a doctrine of the elements of the understanding is bound to be" (A54/B78), as Kant famously puts it. Husserl cites this sentence and adds a remark: “Everyone is familiar with Kant's lectures published by Jäsche, and knows to what a questionable extent they fulfil this characteristic demand” (Prolegomena §58). Similarly, in the passage already quoted above, Husserl complimented Kant for not regarding formal logic as a "worthless scholastic survival" unlike the British empiricists (FTL 265/258). Husserl was thus aware of the fact that Kant did not simply adopt the state of logic from the textbooks of his time. ${ }^{3}$ In this sense, Kant's view of logic can also be said to be 'critical,' but this notion of 'criticism' is obviously not the same transcendental sense of 'criticism' Husserl is concerned with. Independently of whether and to what extent Kant held that general logic really had reached its final state of constituting the pure doctrine of reason, Kant did not see the need for giving it transcendental foundations. Kant asked how pure mathematics is possible, how pure natural science is possible, and how metaphysics in general is possible, but he did not ask how pure logic

\footnotetext{
${ }^{3}$ There is ample evidence that Kant did not simply adopt the state of logic of his time. Even when he claims that with the help of the labors of logicians he was able to exhibit a complete table of the pure functions of the understanding, he added a critical remark, that the labors of logicians were nevertheless "not yet quite free from defects" (Prol. §39). This kind of 'criticism,' however, does not count as transcendental criticism of logic, of the type "how is X possible?," which is Husserl's concern.
} 
is possible. Hence, in Husserl's view his critical philosophy does not extend to his view of pure and general logic. 4

Husserl's further elaboration shows the generality on which his level of discussion of Kant's logic resides. Husserl thinks that Kant's failure to notice the need for transcendental foundations of logic also shows Kant's implicit indebtedness to Hume, who in fact "was the first to grasp the universal concrete problem of transcendental philosophy" (FTL, 257). But while Hume raised the transcendental problem of the constitution of the world, he failed to see the transcendental problem of the constitution of ideal objectivities and, in particular, of the logical idealities (FTL, 266-267/259-260). This shows Hume's unquestioning acceptance of the relations of ideas, which Kant then adopted in his reaction against Hume (FTL 267/260):

Hume directed his criticism to experience and the experienced world, but accepted the unassailableness of the relations of ideas (which Kant conceived as the analytic Apriori). Kant did the same with his counter-problem: He did not make his analytic Apriori a problem. (ibid.)

In Husserl's view, despite their differences, Hume and Kant share an analogous trust in the relations of ideas and the analytic apriori, respectively. In Husserl's view, this kind of unquestioned reliance on logic plagued also the rationalist tradition since Descartes, and it was also held among the transcendental philosophers after Kant (cf. esp. Crisis $\S \S 21,25,30)$. Husserl thinks that it led Kant to use "a mythically, constructively inferring [schliessende] method" instead of a "thoroughly intuitively disclosing [erschliessende] method” (Crisis, §30). In Husserl’s eyes, Kant however came close to employing the latter method in the A-deduction, in which Kant attempted

\footnotetext{
${ }^{4}$ In contemporary discussions, a similar criticism towards Kant has been raised by Sher (2016, 241-242). She is a defender of another critical view of logic: "It is an interesting and a puzzling fact that a systematic philosophical foundation for logic has rarely been attempted. What I have in mind is a unified theoretical foundation, focused on logic itself rather than on mathematics, science, or natural language. Such a foundation would be critical and explanatory, and it would be especially concerned with the veridicality of logic. In connection with this concern it would critically examine the basic features of logic, the tasks logic is designed to perform, the source of truth and falsehood of logical and metalogical claims, the grounds on which logical theories should be accepted (rejected, or revised), the ways logical theories are both constrained and enabled by the human mind on the one hand and the world on the other, the relations between logic and related disciplines (e.g., mathematics), the normativity of logic, and so on." (ibid., 239).
} 
a direct grounding, one which descends to the original sources, only to break off again almost at once without arriving at the genuine problems of foundation which are to be opened up from this supposedly psychological side. (Crisis, §28) ${ }^{5}$

In Husserl's view, general logic, its forms of judgments and syllogisms, should not be unquestionably assumed in a critique of knowledge. A radical critique should not use inferences or logical "deductions" either. Reminiscent of Frege's recourse to elucidations and Wittgenstein's say-show distinction, Husserl's criticism stems from his view that proper transcendental philosophy seeks to clarify logic by describing its intuitive sources (LI 1, §§1-7). For this reason, sciences and logic are excluded from the phenomenological method in the phenomenological "reductions," as described in Ideas I. Phenomenological description should not presuppose them and use them but examine their givenness and constitution (Ideas I, §59). ${ }^{6}$ Kant, however, in Husserl's view, does exactly this. He presupposes general logic and logical deductions in building his view of the apriori. Consequently, this inferring [schliessende] method results in "mythical constructions" or in "constructive concepts which resist in principle an ultimate clarification” (Crisis, §57). ${ }^{7}$

\section{Husserl on Formal Logic}

In terms of logic, Husserl's hero is Leibniz and his attempt at mathesis universalis:

Leibniz, in short, had intuitions of genius: he foresaw the most splendid gains which logic has had to register since the time of Aristotle, the theory of probabilities and mathematical analyses of (syllogistic and non-syllogistic)

\footnotetext{
${ }^{5}$ In Ideas I Husserl claims similarly that in his A-deduction Kant operated entirely within transcendental phenomenology, but Kant misinterpreted that realm as psychological and thus abandoned it (Ideas I, §62).

${ }^{6}$ To be sure, Husserl's phenomenological philosophy is not restricted to the transcendental phenomenological descriptions but utilizes different kinds of methods, including argumentation.

7 In Erste Philosophie [1925] Husserl is more elaborate about what he means by "mythical constructions": "Natürlich müssen wir von vornherein alle dem phänomenologischen Transzendentalismus, und damit dem tiefsten Sinn und Recht des Kantischen, widerstreitenden, in der schlechten Wortbedeutung 'metaphysischen' Bestandstücke der Vernunftkritik (wie die Ding-an-sich-Lehre, die Lehre vom intellectus archetypes, die Mythologie der transzendentalen Apperzeption oder des 'Bewußtseins überhaupt" usw.) übergehen und seinem mythischen Begriffe des Apriori den phänomenologsich geklärten Begriff des allgemeinen Wesens und Wesesgesetzes substituieren... " (Husserl 1956, 235).
} 
arguments. The latter first matured in the second half of the nineteenth century. Through his Combinatoria he is also the intellectual father of the pure theory of manifolds, a discipline close to pure logic and in fact intimately one with it. (Prolegomena, §60)

With Leibniz's mathesis universalis as his guiding idea, Husserl's view of pure logic covers much more than syllogistics or any other theories of inference. It also includes the pure theory of pluralities [Vielheitslehre], pure theory of number, etc., and eventually theories of such theories, like Riemannian theory of manifolds, Grassmann's theory of extensions, Cantor's set theory (Prolegomena §§68, 70).

Husserl's logic encompasses all of mathematics also in his mature view, as expressed in FTL. ${ }^{8}$ In it, logic is conceived of as a combination of a theory of judgments (what Husserl calls 'apophantic logic') and a formal ontology. Instead of the narrow concept of judgment in the traditional logic, Husserl counts among acts of judgment also acts of collecting, counting, ordering and combining mathematically (FTL, 112/ 107; 269/262). Thus, to the pure theory of judgments belong, according to Husserl, "not only the whole of syllogistics, so far as its essential content is concerned, but also (as we shall show) many other disciplines, namely those of formal-mathematical 'analysis'”' (FTL, 60/55). Insofar as the objects of these acts of judgments are abstract, pure objectivities, they are also included in Husserl's concept of 'formal logic.' Indeed formal logic embraces formal ontology, which as a formal apriori theory of objects covers all of pure mathematics, including also non-apophantic mathematics. The latter includes traditional analysis, set theory, theories of combinations and permutations, cardinals or ordinals belonging to various levels, of manifolds, etc. [die traditionelle formale "Analysis" der Mathematiker, die Mathematik der Mengen, der Kombinationen und Permutationen, der Anzahlen (der Modi des Wieviel), der Ordinalzahlen verschiedener Stufe, der Mannigfaltigkeiten] (FTL, 81/ 77)). Husserl's more recent heroes in the development of logic are Riemann and Hilbert. Thanks to Hilbert's axiomatic approach, a clearly defined concept of a complete form of a theory was achieved around the turn of the century (FTL, §31). Riemann's theory of manifolds in turn provides a universal, formal theory of such forms

\footnotetext{
${ }^{8}$ FTL is according to Husserl's own assessment, his "most mature" work, even if "too concentrated" (Schuhmann 1977, 484-485).
} 
of manifolds. With it, the development of modern mathematics towards increasing abstraction culminates in "having also gone on to view such system-forms themselves as mathematical objects" (FTL, 97/93). Husserl's view of formal logic ultimately includes formal structures and their relations to each other.

Husserl thinks that his major achievement in FTL is that he managed to clarify the relationship between formal logic and formal mathematics (FTL, 15/11). After extended analysis of this, Husserl's conclusion is that there is no other difference between mathematics and formal logic than the following: The full notion of formal logic includes the considerations of truth and hence a "logical interest" towards the actually existing world. ${ }^{9}$ Formal logic thus comes with a division into three levels. These are the pure logical grammar, the logic of non-contradiction, and the truth-logic. On different levels of logic, different kinds of evidence is sought: pure logical grammar aims at evidence in the most general sense [Evidenz im weitesten Sinne], logic of noncontradiction at the evidence of distinctness [Deutlichkeit], and finally truth at clarity [Klarheit], which requires an encounter with the world (for details, see Heffernan 1989, esp. §7, 144-153). These evidences are normative ideals for the practices. The difference between mathematics and formal logic is that they are guided by different normative ideals: Mathematics is only concerned with grammaticality and non-contradiction, while formal logic, conceived fully, includes also what Husserl calls logic of truth,' in addition to pure logical grammar and logic of non-contradiction. Mathematics is thus concerned only with the first two kinds of evidences, whereas formal logic is concerned with all three.

The source of evidence of distinctness lies in the harmonious unity of possible experience, in which the contents of judgments have the coherence of matters in the

\footnotetext{
${ }^{9}$ Husserl writes: "a formal mathematics, reduced to the above described purity, has its own legitimacy and that, for mathematics, there is in any case no necessity to go beyond that purity. At the same time, however, a great advance is made philosophically by the insight that such a restrictive reduction of logical mathesis (formal logic, when it has attained the completeness befitting its essence) - namely its reduction to a pure analytics of noncontradiction-is essentially its reduction to a science that has to do with nothing but apophantic senses, in respect of their own essential Apriori, and that in this manner the proper sense of 'formal mathematics', the mathematics to which every properly logical intention (that is: every intention belonging to a theory of science) remains alien - the mathematics of mathematicians - at last becomes fundamentally clarified. Here lies the sole legitimate distinction between formal logic and mere formal mathematics" (FTL, 146/140-141).
} 
synthetic unity of experience [der synthetischen Einheit der Erfahrung], also referred to as a universe of possible experience [ein Universum möglicher Erfahrung], or a unitary sphere of experience [ein einheitliche Erfahnungssphäre, ein einheitliches sachliches Gebiet] (FTL, §§89b). From the present post-Tarskian point of view, the source of distinctness appears to lie in the existence of a "model" provided by such a synthetic unity of experience. The sense of mathematics, according to Husserl, is thus to strive for non-contradictory theories and build "models" for them to acquire distinct evidence of the harmony of the synthetic unity of experience in question.

Truth, excluded from the interests of the mathematicians, for Husserl means "a correct critically verified judgment-verified by means of an adequation to the corresponding categorial objectivities "themselves," as given in the evidential having of them themselves" (FTL, 132/127). The evidence of clarity thus involves an encounter with the actual world, hence going outside the formal realm to the world. This may take place in two ways, either directly, by applying the theories (as in applied mathematics, e.g., geometry or mechanics), or else through a "transitional link," which is a judgment theory in which complex formations can be reduced to elementary judgments about objects (FTL §§83-84). In both cases, the ultimate goal of formal logic is to acquire fulfilment by means of perception of individual objects and judgments about them. One might think that, with the inclusion of the domains of theories in his concept of formal logic, Husserl came close to formulating something like a Tarskian notion of logical consequence. However, Husserl is not at all interested in capturing the notion of validity of reasoning. He considers theories of inferences, syllogisms, and also tautologies, as separate theories within the logic of non-contradiction. He is not searching for one overarching theory of inference, or formulation of logical consequence. None of the theories of inference he mentions has any systematic role to play in his view of reasoning. Instead, his primary interest is in complete and exhaustive description of different kinds of structures and their relationships with each other. This characteristic of his view of logic can be usefully captured through Hintikka's (2003) distinction between two roles that logic may have in mathematics. Whereas the deductive function emphasizes mathematical practice as theorem proving, the descriptive function of logic aims to characterize the structures exemplified by the 
intended models of the theory. Husserl's interest is clearly in the latter: Logic is about describing formal structures rather than about reasoning. Kant would probably not think of this as proper logic, at least, not as proper general logic, which has a deductive, rather than a descriptive, function.

Formal logic as characterized above can be converted into a normative "technological" discipline (FTL, 35/31). Husserl explained this in more detail already in his Prolegomena (1900):

A little reflection will make matters clear. Every law of pure logic permits of an (inwardly evident) transformation, possible a priori, which allows one to read off certain propositions about inward evidence, certain conditions of inward evidence, from it. The combined principles of contradiction and excluded middle are certainly equivalents to the proposition: one and only one of two mutually contradictory judgements can manifest inner evidence. (Prolegomena §49)

The conversion is based on a general equivalence between the proposition 'A is true' and 'It is possible for anyone to judge A to be true in an inwardly evident manner' (Prolegomena §49). This process assumes an establishment of general propositions, so that

with an eye to a normative standard, an idea or highest goal, certain features are mentioned whose possession guarantees conformity to that standard, or sets forth an indispensable condition of the latter. (Prolegomena §11)

Accordingly, later, after having distinguished between the highest goal of logic and that of mathematics, Husserl discusses the logical principles (the principle of contradiction and principle of exclude middle, modus ponens, and modus tollens) in FTL, first as principles of the logic of non-contradiction and then as principles of the logic of truth, hence relative to the normative ideals or highest goal of the formal theory in question. In both cases, they are given an objective and a subjective version. The objective versions are claims about ideal mathematical existence (logic of non-contradiction) or possibility of adequation (truth-logic), but taken subjectively, the principles relate to subjective performances. The subjective versions of the logical principles of the traditional logic relate to reasoning. They issue norms such as "[o]f two judgments that (immediately or 
mediately) contradict one another, only one can be accepted by any judger whatever in a proper or distinct unitary judging" (FTL, 197/ 190). These norms are justified if they are derived from the objective principles. The subjective principles like these then establish laws of reasoning, hence something closer to Kant's general logic. But in contrast to Kant's view, the scope of the logical principles is not assumed to be general. As we will soon see, the scope of application of these principles should not be uncritically accepted. Rather, it is ultimately a matter of transcendental scrutiny with a view to the ideal goals of the underlying formal theory.

\section{Husserl's critique of Kant}

With this notion of logic in the background, Husserl's criticism of Kant in FTL should now be perfectly clear. Husserl writes:

Kant's logic is presented as a science directed to the subjective- a science of thinking, which is nevertheless distinguished, as apriori, from the empirical psychology of thinking. But actually, according to its sense, Kant's purely formal logic concerns the ideal formations [idealen Denkgebilde] produced by thinking. And, concerning them, Kant fails to ask properly transcendental questions of the possibility of cognition (FTL, 267/260).

Even though Kant's logic is concerned with the subjective, Husserl concedes that, strictly speaking, Kant's purely formal logic also comes with intentions towards ideal formations. Kant, in speaking of forms of thinking, implicitly commits himself to some sort of ideality. Indeed, Husserl held that Kant and other proponents of 'formal' or 'pure' logic had correct intentions, "but not rightly conceived and defined by them as regards its content and scope" (Prolegomena §3).

Why, then, does Husserl claim that it is subjective? As alluded to before, the reason for this is presumably that Kant's general logic is about rules for thought, like Husserl's subjective versions of the logical principles discussed above. In this respect, Husserl finds Kant's view of logic "subjective" - it is about acts of reasoning by a subject. Logic is discussed in an inferential rather than in a descriptive role. Kant's view of general logic 
thus is a priori and theoretical, but it falls short in its content and scope. Kant's logic yields a subjective, albeit a priori, theory of reasoning. Hence, it, and everything constructed by means of it, including the sciences, is subjective:

Like the intuited world of bodies, the whole world of natural science (and with it the dualistic world which can be known scientifically) is a subjective construct of our intellect; only the material of the sense-data arises from a transcendent affection by 'things in themselves.' (Crisis, §25)

Consequently, Kant managed to create "a new sort of transcendental subjectivism which begins with Kant and changes into new forms in the systems of German idealism” (§25). Husserl thinks that in its directedness to the subjective Kant's logic is too restricted, because the ideal formations, which logic intends to be about, are nevertheless excluded from the realm of logic. Husserl thinks that "the ideality of the formations with which logic is concerned [should be taken] as the characteristic of a separate, self-contained, 'world' of ideal objects" (FTL, 267/261). Kant thus "did not grasp the peculiar sense in which logic is ideal. Otherwise that sense would surely have given him a motive for asking transcendental questions" (FTL, 267/261). As we saw above, Husserl's view of the ideality or abstractness of logic not only leads to inclusion of "semantics" in his conception of logic. It also makes him see a role for logic in description of formal structures and their relationships to each other, as in Hilbert's view of axiomatics embedded in a general theory of manifolds. For Husserl, logic is ideal in the sense that it has ideal content that is given by abstract structures. Here, Kant's view of formal logic is closer to the way many contemporary philosophers conceive of logic, whereas Husserl's view is a "mathematician's" view of logic, including formal ontology as a theory of formal structures.

Husserl's mature criticism of Kant's view of logic curiously resonates with a way in which Husserl earlier thought that the pure idea of logic necessitated categorial intuition. Whereas for Kant, intuitions and categories belong to different faculties, so that the very notion of categorial intuition would be nonsensical for him, for Husserl the term captures the idea that categorial structures-the ideal structures that the world assumes-are outside of us. Through categorial intuition, categorial objectivities (such 
as states of affairs) are given to us. At the time of discussing it (i.e., in Logical Investigations, 1900-1901), Husserl had not yet explicitly formulated his own philosophy as transcendental philosophy. But insofar as transcendental philosophy is a study of subjective achievements that make objective knowledge possible, 'categorial intuition' was already a transcendental philosophical concept. The main change in Husserl's later view is that categorial intuition is further differentiated into different kinds of evidences (e.g., distinctness and clarity) with which formal sciences are given. In particular, his view of distinctness as an evidence related to a non-contradictory theory is novel in FTL. While categorial intuition is founded on perceived individuals, evidence of distinctness arises within the formal theory itself, without any comparison with the world. ${ }^{10}$

Husserl then thinks that once one has obtained the correct view of the abstractness of logic it should be clear that it has to be subjected to transcendental scrutiny. Indeed, understanding formal logic as a study of structures makes it rather obvious that, parallel to the transcendental problems of nature, it too has to be subjected to criticism:

the transcendental problem that objective logic (taken no matter how broadly or narrowly) must raise concerning its domain of ideal objectivities takes a position parallel to the transcendental problems of the sciences of realities, the problems that must be raised concerning the regions of realities to which those sciences pertain, and in particular, the transcendental problems concerning nature, which were treated by Hume and Kant. It seems, then, that the immediate consequence of bringing out the world of ideas and, in particular (thanks to the effectuation of impulses received from Leibniz, Bolzano, and Lotze), the world of ideas with which pure logic is concerned, should have been an immediate extension

\footnotetext{
${ }^{10}$ Categorial intuition is crucial to Husserl's notion of truth discussed in Logical Investigation (1900-1901). It is founded on sensuous perception of immediately given objects so that in it, e.g., a state of affairs that encompasses also the ideal formation of the objects, is constituted (esp. LI 6, §§45-48). Transcendental philosophy can be viewed as a study of how the objective senses and validities are constituted, i.e., in what way they are achievements of subjectivity. Thus, categorial intuition is one such achievement, that is, constitution of e.g., states of affairs. Husserl claims to have discovered this "apriori of correlation," i.e., the correlation between objectivities (states of affairs) and their constitution, in 1898: "[t]he first breakthrough of this universal a priori of correlation between experienced object and manners of givenness (which occurred during work on my Logical Investigations around 1898) affected me so deeply that my whole subsequent life-work has been dominated by the task of systematically elaborating on this a priori of correlation" (Crisis 166n).
} 
[sofortige Übertragung] of transcendental problems to this sphere. (FTL, $271 / 264)$

Even with all the problems Husserl finds in Kant, he (Husserl) nevertheless thinks that Kant's philosophy is on a way to proper transcendental philosophy, "that it is in accord with the formal, general sense of a transcendental philosophy in our definition" (Crisis §27). Indeed, he writes that, if Hume is counted out, "the Kantian system is the first attempt, and one carried out with impressive scientific rigorousness, at a truly universal transcendental philosophy..." (Crisis §27). But, due to his subjective conception of logic and "inferring" method, Kant managed to build a philosophy restricted to "transcendental subjectivism" (Crisis §25). Thus, Kant’s aim - to establish the scope and limits of reason - led him, for example, to distinguish between appearances and things in themselves, whereas Husserl finds such "metaphysical" constructions unfounded.

5. Parsons's and Husserl's Critical views of logic

Charles Parsons (2015) has introduced the term 'critical view of logic' to characterize positions that question the putative self-evidence of logic, in particular, the applicability of the usual logical laws in mathematics. "The basic idea of the view is that we cannot take for granted the familiar logical principles and inferences in doing mathematics, in particular when our reasoning involves the infinite, even in the very low-level way in which the infinite enters into reasoning about natural numbers" (2015, 2). While an obvious pioneer of the view is Brouwer, Parsons holds that the critical view could also be had independently on constructivist grounds. For Parsons, the view relates to what he calls 'entanglement of logic and mathematics,' which refers to the way in which one's choice of logic is dependent on one's mathematical commitments (Parsons 2015, 13). The view thus is "mathematics-first and philosophy-second" - it does not impose restrictions upon logic for philosophical reasons, but for reasons that have to do with the nature of the subject matter.

To obtain a critical view of logic, Husserl subjects formal logic, as discussed above, to a transcendental scrutiny. This takes place in transcendental logic: 
Logic must overcome its phenomenological naivete; even after having learned to recognize that which is ideal, logic must be more than a merely positive science of logico-mathematical idealities. Rather, with a continuously two-sided research (results on either side determining inquiries on the other), logic must go back systematically from the ideal formations to the consciousness that constitutes them phenomenologically; it must make these formations understandable, in respect of their sense and their limits, as essentially products of the correlative structures of productive cognitive life, and it must thereby fit them, like each and every other objectivity, to the broader, the concrete, nexus of transcendental subjectivity. The ideal objectivity of the formations with which logic is concerned - like the real world- is in no way altered in the process. (FTL, 270/263)

Transcendental logic thus examines the way in which formal logic relates to the consciousness that has constituted it. This does not mean that formal logic is constructed and that Husserl's view is constructivistic. ${ }^{11}$ Rather, to him formal logic is what it is to mathematicians, it is likewise approached from the "mathematics first" stance. The task of transcendental philosophy is to understand and clarify how it is given to us; it is not to force it into any particular form of givenness. It thus studies the kinds of evidences in which logic is given, what kinds of presuppositions logic relies on, and how all this is connected to form a harmonious whole ultimately related to our lives. This means that formal logic has to be examined and clarified in a transcendental phenomenological attitude. Whereas in Ideas I Husserl effects the required change of attitude with the "epoché" and the phenomenological "reductions" more or less in one blow, in FTL his path is much more gradual. Husserl starts by looking at the evidences with which different layers of formal logic are given. These are then clarified and purified so that possible overlaps of evidences and other such confusions are revealed. He writes, "evidence of every sort ... should be reflectively considered, reshaped, analyzed, purified, and improved; and that afterwards it can be, and ought to be, taken as an exemplary pattern, a norm." (FTL, 184/176). Examination of evidences brings to the fore various kinds of presuppositions that are assumed in formal logic. These are, for

\footnotetext{
${ }^{11}$ I explain the differences between constitution and construction in detail in Hartimo (Forthcoming).
} 
example, the ideality of judgments, reiteration 'and so forth,' and the aforementioned logical principles. Husserl discusses the logical principles separately for the logic of noncontradiction and for the truth-logic; hence, their validity is discussed relative to the evidences governing the discipline in question. Furthermore, in both cases, the principles are discussed in both an objective and a subjective formulation, where the latter is "an evidential correlate" of the former. Husserl then examines the kinds of evidences presupposed in these principles. Without this kind of examination, a false range of application may be attributed to them:

Because of the formal abstractness and naïveté of the logician's thinking, such never-formulated presuppositions can easily be overlooked; and consequently a false range can be attributed even to the fundamental concepts and principles of logic. (FTL 207/200)

A logic that accords with a critical view of logic is thus a transcendentally clarified logic. It is any logic or mathematics that is fully cognizant of its own aims and the kinds of evidence related to these. The evidences are clarified and purified, so that, e.g., distinctness and clarity are not confused with each other, the employed basic concepts are correct and used with their proper scopes, likewise the employed logical principles are in accordance with the demands of various evidences and used only where explicitly deemed valid. For Husserl, only science examined in this way is genuine science. Such a science is not plagued by paradoxes:

Truth is that science that have paradoxes, that operate with fundamental concepts not produced by the work of originary clarification and criticism, are not sciences at all but, with all their ingenious performances, mere theoretical techniques. (FTL, 189/ 181)

Logic or mathematics, for Husserl, should not be a mere (even if fun) game, but it should serve critically examined purposes with clarified concepts and principles with corrected scopes of application. This means to adopt the "radicalness of scientific selfresponsibility" [Radikalismus wissenschaftlicher Selbstverantwortung] (FTL, 8/4). Husserl's critical view of logic accords well with Parsons's formulation in so far as it demands a reflective justification of the usage for the familiar logical principles and 
inferences. The clear difference between the two is that for Husserl the applicability of logical principles is examined in relation to the goals and evidences that are sought in each discipline. This suggests that the applicability of logical principles should be assessed relative to the normative standards that govern the chosen methods (e.g., whether proofs should be constructive, whether definitions should be predicative, etc.), which leads to a more pluralistic approach. The approach is still revisionary, even though moderately so. In it, the concepts and principles of various disciplines can be revised, but this criticism takes place internally, against the standards of each discipline. For Parsons, the source of critique lies in certain mathematical facts (e.g., about sizes of domains). His approach emphasizes the entanglement of mathematics and logic, and, accordingly, his level of analysis is technically much more refined than it is in Husserl. For the foundations of contemporary logic, a combination of these two views appears most promising. In this sense, a critical view of logic should include reflection on the choice and scope of normative standards that also takes into account the nature of the domain in question. ${ }^{12}$

\section{Conclusion}

On Husserl's view, formal logic is more comprehensive than Kant's general logic. It comprises all the formal sciences that aim at different kinds of evidence. Husserl's logic is about formal structures, whereas Kant's view of general logic is about laws of reasoning. This is why Husserl claims that Kant's view of general logic is directed to the subjective, whereas his own view of logic is rather directed towards the objective that is needed to justify the subjective principles. This makes a difference also with regard to the role of logic in each philosopher's critical philosophy: While general logic is a starting point and neutral tool for Kant's critical endeavor, Husserl's formal sciences are subjected to a critical reflection in what Husserl calls "transcendental logic," which is not what Kant means by "transcendental logic." Consequently, for Kant categories have

\footnotetext{
${ }^{12}$ Husserl's view of logic differs from Sher's (2016) critical view of logic, in that she attempts to give logic theoretical foundations, while Husserl wants to give logic transcendental foundations that reveal the very conditions of possibility of logic. The way both approaches use the notion of invariance invites further comparison, which, however, has to be left for another occasion.
} 
their basis in the understanding, whereas for Husserl categoriality is out there in the world or in the realm of ideal formations. While Husserl thinks that Kant fails to ask transcendental questions about logic, and hence to formulate a critical view of logic, for Husserl critical logic is to be identified with transcendentally reflected logical pluralism. It is a formal science carried out with an explicit awareness of the purposes of its diverse approaches and the constitution of the used principles and concepts with respect to the aims of the formal theory in question.

References with abbreviations:

FTL Husserl, Edmund (1974). Formale und transzendentale Logik: Versuch einer Kritik der logischen Vernunft (1929). Husserliana XVII. Ed. P. Janssen. The Hague: Martinus Nijhoff. English translation: Formal and Transcendental Logic, translated by Dorion Cairns. Martinus Nijhoff. The Hague. 1969.

Ideas I Edmund Husserl (1976). Ideen zu einer reinen Phänomenologie und phänomenologischen Philosophie. Erstes Buch: Allgemeine Einführung in die reine Phänomenologie. Husserliana III. Ed. K. Schuhmann. The Hague: Martinus Nijhoff. English Translation: Ideas pertaining to a pure phenomenology and to a phenomenological philosophy, translated by F. Kersten. Kluwer, Dordrecht, Boston, London.1982.

LI 1-6. Edmund Husserl. Logische Untersuchungen. Zweiter Band. Untersuchungen zur Phänomenologie und Theorie der Erkenntnis. Husserliana XIX, Edited by Ursula Panzer. Martinus Nijhoff. The Hague, 1984. English translation Logical Investigations, translated by J. N. Findlay. Volumes One \& Two. Humanities Press. New York, 1970.

Prolegomena Edmund Husserl (1975). Logische Untersuchungen. Erster Band. Prolegomena zur reinen Logik. Husserliana XVIII. Ed. E. Holenstein. The Hague: Martinus Nijhoff. English translation in Logical Investigations, translated by J. N. Findlay. Volume One. Humanities Press. New York, 1970.

Crisis Husserl, Edmund (1976). Die Krisis der europäischen Wissenschaften und die transzendentale Phänomenologie: Eine Einleitung in die phänomenologische Philosophie (1936). Husserliana VI. Ed. W. Biemel. The Hague: Martinus Nijhoff. English translation: The Crisis of European Sciences and Transcendental Phenomenology. An Introduction to Phenomenological Philosophy. Translated by David Carr. Evanston: Northwestern University Press, 1970.

A/B Kant, Immanuel. (1998). Critique of Pure Reason. Edited and translated by Paul Guyer and Allen W. Wood. New York: Cambridge University Press.

Prol Kant, Immanuel. (1977). Prolegomena to any Future Metaphysics. Translated by Paul Carus, revised by James W. Ellington. Indianapolis/Cambridge: Hackett Publishing Company.

Further references: 
Hartimo, Mirja (2018). "Husserl on completeness, definitely." Synthese 195, 2018: 1509-1527.

Hartimo, Mirja (Forthcoming). "Constitution and Construction” to appear in Weiss, Christina (ed.). Constructive Semantics - Meaning in Between Phenomenology and Constructivism. Logic, Epistemology and the Unity of Science Series. Springer.

Heffernan, George (1989). Isagoge in die phänomenologische Apophantik. Eine Einführung in die phänomenologische Urteilslogik durch die Auslegung des Textes der Formalen und transzendentalen Logik von Edmund Husserl. Dordrecht, Boston, London: Kluwer Academic Publishers.

Hintikka, Jaakko (2003). The Principles of Mathematics Revisited. Cambridge: Cambridge University Press. [1996]

Husserl, Edmund (1956). Erste Philosophie (1923/24). Erster Teil, kritische Ideengeschichte. Husserliana volume VII, edited by Rudolf Boehm. Haag: Martinus Nijhoff.

Parsons, Charles (2012). "Arithmetic and the Categories." In: From Kant to Husserl. Cambridge, Mass.: Harvard University Press: 42-68.

Parsons, Charles. (2015). "Infinity and a Critical View of Logic." Inquiry 58/1: 1-19.

Schuhmann, Karl (1977). Husserl-Chronik, Denk- und Lebensweg Edmund Husserls. The Hague: Martinus Nijhoff.

Sher, Gila (2016). Epistemic friction: an essay on knowledge, truth, and logic. Oxford University Press. 